\title{
Knowledge of orthodontic tooth movement through the maxillary sinus: a systematic review
}

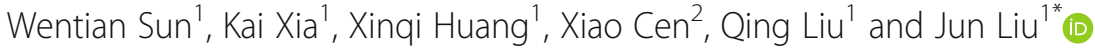

\begin{abstract}
Background: To investigate the feasibility, safety and stability of current interventions for moving teeth through the maxillary sinus (MTTMS) by performing a systematic review of the literature.

Methods: The electronic databases PubMed, Embase, CENTRAL, Web of Science, CBM, CNKI and SIGLE were searched without a language restriction. The primary outcomes were parameters related to orthodontic treatment, including orthodontic protocols, magnitude of forces, type of tooth movement, duration and rate of tooth movement, and remolding of alveolar bone and the maxillary sinus floor. The secondary outcomes were safety and stability, including root resorption, perforation of the sinus floor, loss of pulp vitality and periodontal health and relapse.

Results: Nine case reports with 25 teeth were included and systematically analyzed. Fifty to two hundred g of force was applied to move teeth through the maxillary sinus. Bodily movement was accomplished, but initial tipping was observed in 7 cases. The rate was $0.6-0.7 \mathrm{~mm} /$ month for molar intrusion and $0.16-1.17$ and $0.05-0.16 \mathrm{~mm} / \mathrm{month}$ for mesial-distal movement of premolars and molars, respectively. Bone formation and remolding of the sinus floor occurred in 7 cases. Root resorption within 6 to 30 months was observed in 3 cases, while no cases of perforation of the sinus floor, loss of pulp vitality, periodontal health impairment or relapse were reported.

Conclusions: At the present stage, no evidence-based protocol could be recommended to guide MTTMS. The empirical application of constant and light to moderate forces (by TAD, segment and multibrackets) to slowly move teeth through or into the maxillary sinus in adults appears to be practical and secure. Bodily movement was accomplished, but teeth appear to be easily tipped initially, potentially resulting in root resorption. However, this conclusion should be interpreted with caution as the currently available evidence is based on only a few case reports or case series and longitudinal or controlled studies are lacking in this area.
\end{abstract}

Keywords: Intrusion, Maxillary sinus, Orthodontics, Root resorption, Systematic review, Tooth movement

\section{Background}

With the development of digitalization and material science in the past few decades, substantial progress has been achieved in orthodontic techniques for more efficient, precise, invisible, comfortable and rapid treatment [1-3]. However, orthodontists commonly encounter predicaments related to dental status, periodontal status, general health, orthodontic technique, anchorage, and other factors that may limit orthodontic treatment [4].

\footnotetext{
* Correspondence: junliu@scu.edu.cn

${ }^{1}$ State Key Laboratory of Oral Diseases, National Clinical Research Center for Oral Diseases, Department of Orthodontics, West China Hospital of

Stomatology, Sichuan University, Chengdu 610041, China

Full list of author information is available at the end of the article
}

Among these challenges, movement of teeth against anatomic structures, such as the maxillary sinus (MS), appears to be non-evidence-based.

The MS is the largest paranasal sinus, located in the posterior maxilla, and has a close relationship with adjacent structures. It sprouts late in fetal life, existing at birth with a dimension of approximately $3 * 6 * 8 \mathrm{~mm}$, and ends its growth in a pyramid shape in adults [5-7]. The MS floor (MSF) consists of a thin bony plate covered with a layer of mucosa. With pneumatization and aging, the floor extends into the posterior alveolar process and forms the alveolar recess, creating protrusions of root apices into the sinus [5]. Generally, the MSF is at the level of nasal floor at puberty

(c) The Author(s). 2018 Open Access This article is distributed under the terms of the Creative Commons Attribution 4.0 International License (http://creativecommons.org/licenses/by/4.0/), which permits unrestricted use, distribution, and 
and reaches its lowest point with the eruption of the third molars [5, 6]. Morphologically, the sinus-root relationship (SRR) can fall into 5 categories: 0 , the root is not in contact with the sinus floor; 1 , the MSF curves inferiorly with the root in contact with the MSF; 2, the MSF curves inferiorly with the root projecting laterally on the sinus cavity but its apex is outside the sinus; 3 , the MSF curves inferiorly with the root apex projecting on the sinus cavity; and 4, the MSF curves superiorly with part or all of the tooth root enveloped [8]. For individuals with excessive pneumatization, a type-1, 2, 3 or 4 relationship can be common.

The classic theory of orthodontic tooth movement stresses the dynamic balance of bone resorption on the pressure side and deposition on the tension side of the periodontal ligament (PDL) [9]. This theory has been successfully applied by orthodontists to move teeth in the alveolar bone. However, applying this concept to the MS, with potential tooth movement against cortex or soft tissue [10], is more difficult. Consequently, clinicians often fear the uncertainty of moving teeth through the maxillary sinus (MTTMS). However, recent experiments have revealed a particular biomechanical pattern regarding MTTMS. Mechanical stress could induce osteogenesis on the sinus side before bone resorption occurred on the PDL side, and the bone thickness of the sinus wall could be maintained [11-13], potentially indicating the feasibility of MTTMS. Furthermore, concurrent root resorption and higher efficiency of light forces were also observed in these experiments [11-13].

In orthodontic clinics, clinicians may encounter MTTMS. In some cases, planning the distalization of molars or the maxillary dentition to correct type-II occlusion or to achieve a better anterior profile is preferred because this technique has the benefit of avoiding extraction and is reported to be one of the advantages of clear aligners $[1,9,14]$. In other cases, when closure of posterior spaces [15-17], tooth intrusion to create spaces for opposing prosthetics $[18,19]$ or an alternative non-surgical sinus lift for implant sites [20-22] is required, orthodontists must implement MTTMS. MTTMS determines the feasibility, duration and quality of comprehensive treatment. No systematic reviews on MTTMS are currently available. The purpose of this research was to systematically review the literature and investigate the feasibility, safety and stability of current interventions for MTTMS.

\section{Methods}

This systematic review was conducted generally following the Preferred Reporting Items for Systematic Reviews and Meta-Analysis (PRISMA) checklist [23]. The literature search, data extraction and quality assessment were all performed independently by two reviewers. Any disagreement was resolved by discussion or by consultation with a third party.

\section{Inclusion criteria}

We set the following inclusion criteria to identify eligible studies: (1) Patients with at least one target tooth, defined as a tooth with at least one root protruding into the MS, were investigated. The morphological SRR (type-2, 3 or 4 for distal-mesial movement and type-1, 2, 3 or 4 for intrusion) must be confirmed by radiological diagnosis: periapical films, panoramics or cone-beam computed tomography (CBCT); (2) An orthodontic treatment to move target teeth through the MS was executed; (3) The primary outcomes were parameters related to orthodontic treatment, including orthodontic protocols, magnitude of orthodontic forces, tooth movement type, duration and rate of tooth movement, and remolding of the alveolar bone and MSF. The secondary outcomes were safety and stability, including orthodontically induced root resorption (OIRR), perforation of the sinus floor (Perforation of the sinus floor should be verified by occurrence of sinusitis or by radiological findings in sinus. The integrity of lamina dura should be assessed by radiography: periapical films, panoramics or CBCT, while the sinus membrane should be assessed with CT/CBCT, MRI or endoscopy [5, 18, 19, 24-28].), pulp vitality loss, and periodontal health impairment and relapse; and (4) The study was a clinical study, including randomized clinical trial, controlled clinical trial, cohort study, case-control study, cross-sectional study and case report.

\section{Search strategy}

Online searches were conducted in electronic databases, including PubMed, Embase, CENTRAL, Web of Science, Chinese Biomedical Literature Database (CBM), China National Knowledge Infrastructure (CNKI), without restriction of language. Grey literature was searched in the System for Information on Grey Literature in Europe (SIGLE). We used MeSH terms as well as free text words, and the key words were "maxillary sinus," "orthodontics," "orthodontic"," "tooth moving," and "tooth movement" for all databases. The reference lists of relevant articles were manually searched for additional studies. The searches were initially conducted in January 2017 and were updated on May 16, 2017.The search strategies are presented in Table 1.

\section{Data extraction and analysis}

Information regarding the characteristics and outcomes of the included studies was extracted. Specifically, the following characteristics were identified: country, age, sex, sample size, target teeth, SRR, source of active force and radiological method. The outcomes were those items defined in the inclusion criteria above. 
Table 1 Search strategies for all databases (updated on May 16, 2017)

\begin{tabular}{|c|c|c|c|c|c|c|c|}
\hline steps & PubMed & Embase & CENTRAL & Web of science & CNKI & CBM & SIGLE \\
\hline 1 & $\begin{array}{l}\text { "Maxillary Sinus" } \\
\text { [Mesh] (9226) }\end{array}$ & $\begin{array}{l}\text { Maxillary Sinus.mp. or } \\
\text { Maxillary sinus/ (14263) }\end{array}$ & $\begin{array}{l}\text { Maxillary Sinus.mp. or } \\
\text { Maxillary Sinus/ (424) }\end{array}$ & $\begin{array}{l}\text { Maxillary Sinus } \\
(21210)\end{array}$ & $\begin{array}{l}\text { Maxillary Sinus } \\
(8251)\end{array}$ & $\begin{array}{l}\text { "Maxillary Sinus" } \\
\text { [Mesh] (3483) }\end{array}$ & $\begin{array}{l}\text { Maxillary } \\
\text { Sinus (26) }\end{array}$ \\
\hline 2 & $\begin{array}{l}\text { Maxillary Sinus } \\
(15823)\end{array}$ & $\begin{array}{l}\text { Orthodontics.mp. or } \\
\text { Orthodontics/ (34932) }\end{array}$ & $\begin{array}{l}\text { Orthodontics.mp. or } \\
\text { Orthodontics/ (636) }\end{array}$ & $\begin{array}{l}\text { Orthodontics } \\
\text { (29732) }\end{array}$ & $\begin{array}{l}\text { Orthodontics } \\
\text { (12742) }\end{array}$ & $\begin{array}{l}\text { Maxillary Sinus } \\
\text { (7208) }\end{array}$ & $\begin{array}{l}\text { Orthodontics } \\
(85)\end{array}$ \\
\hline 3 & $\begin{array}{l}\text { "Orthodontics" } \\
\text { [Mesh] (48362) }\end{array}$ & $\begin{array}{l}\text { Orthodontic*.mp. } \\
\text { (51672) }\end{array}$ & $\begin{array}{l}\text { Orthodontic }{ }^{*} . m p . \\
\text { (2402) }\end{array}$ & $\begin{array}{l}\text { Orthodontic } \\
(67283)\end{array}$ & $\begin{array}{l}\text { Tooth } \\
\text { movement } \\
(1045)\end{array}$ & $\begin{array}{l}\text { "Orthodontics, } \\
\text { Corrective" } \\
\text { [Mesh] (11645) }\end{array}$ & $\begin{array}{l}\text { Orthodontic* } \\
\text { (235) }\end{array}$ \\
\hline 4 & $\begin{array}{l}\text { Orthodontics } \\
\text { (63379) }\end{array}$ & $\begin{array}{l}\text { Tooth } \\
\text { moving.mp. (12) }\end{array}$ & $\begin{array}{l}\text { Tooth } \\
\text { movement.mp. or } \\
\text { Tooth } \\
\text { Movement/ (382) }\end{array}$ & $\begin{array}{l}\text { Tooth moving } \\
(54506)\end{array}$ & 2 OR 3 (15616) & $\begin{array}{l}\text { Orthodontics } \\
\text { (16725) }\end{array}$ & $\begin{array}{l}\text { Tooth } \\
\text { movement (14) }\end{array}$ \\
\hline 5 & $\begin{array}{l}\text { Orthodontic* } \\
\text { (62688) }\end{array}$ & $\begin{array}{l}\text { Tooth } \\
\text { movement.mp. (2970) }\end{array}$ & 2 OR 3 OR 4 (2423) & $\begin{array}{l}\text { Tooth } \\
\text { movement } \\
(59130)\end{array}$ & 1 AND 4 (23) & $\begin{array}{l}\text { "Tooth movement" } \\
\text { [Mesh] (1104) }\end{array}$ & $\begin{array}{l}\text { Tooth } \\
\text { moving (3) }\end{array}$ \\
\hline 6 & $\begin{array}{l}\text { "Tooth } \\
\text { Movement } \\
\text { Techniques" } \\
\text { [Mesh] (7834) }\end{array}$ & $\begin{array}{l}2 \text { OR } 3 \text { OR } 4 \text { OR } 5 \\
(52143)\end{array}$ & 1 AND 5 (1) & $\begin{array}{l}2 \text { OR } 3 \text { OR } 4 \\
\text { OR } 5 \\
(157498)\end{array}$ & & $\begin{array}{l}\text { Tooth movement } \\
(2280)\end{array}$ & $\begin{array}{l}2 \text { OR } 3 \text { OR } 4 \\
\text { OR } 5 \text { (245) }\end{array}$ \\
\hline 7 & $\begin{array}{l}\text { Tooth } \\
\text { movement } \\
\text { (10981) }\end{array}$ & 1 AND 6 (125) & & 1 AND 6 (305) & & 1 OR 2 (7208) & 1 AND $6(0)$ \\
\hline 8 & $\begin{array}{l}\text { Tooth } \\
\text { moving (327) }\end{array}$ & & & & & $\begin{array}{l}3 \text { OR } 4 \text { OR } 5 \text { OR } 6 \\
(18312)\end{array}$ & \\
\hline 9 & 1 OR 2 (15823) & & & & & 7 AND 8 (28) & \\
\hline 10 & $\begin{array}{l}3 \text { OR } 4 \text { OR } 5 \text { OR } \\
6 \text { OR } 7 \text { OR } 8 \\
\text { (71532) }\end{array}$ & & & & & & \\
\hline 11 & 9 AND 10 (195) & & & & & & \\
\hline
\end{tabular}

CENTRAL Cochrane Central Register of Controlled Trials, CNKI China National Knowledge Infrastructure, CBM Chinese Biomedical Literature Database, SIGLE System for Information on Grey Literature in Europe

\section{Results}

\section{Characteristics of the included studies}

The online search yielded 677 articles. After excluding duplicate and irrelevant articles by reading titles and abstracts, 11 full texts remained. Then, the reference lists of these articles were read and one additional study was identified. No prospective or retrospective controlled clinical studies were found. Nine case reports meeting the inclusion criteria were included and systematically analyzed (Fig. 1). The characteristics of the 9 case reports are presented in Table 2.

\section{Results of quality assessment}

All included studies were case reports and consequently had a relatively high risk of bias.

\section{Study outcomes analysis}

In total, nine adult subjects with 25 target teeth were included. All target teeth had a type-2, 3 or 4 SRR (Table 3).

\section{Protocol and magnitude of forces}

Cacciafesta et al. [17] used segments to protract tooth numbers 27 and 28 mesially, and the force was $50 \mathrm{~g}$ by coil spring. Re et al. [22] used an endosseous implant in the retromolar area and a T-loop to move tooth number 25 distally, and the active load was $50 \mathrm{~g} / \mathrm{mm}$. In Kravitz et al.'s article [18], tooth number 16 was intruded using temporary anchorage devices (TADs), and the forces were $100 \mathrm{~g}$ by elastic power chain in the initial 2 months and $150 \mathrm{~g}$ by coil spring in the next 4 months. Yao et al. [19] also used TADs to intrude two adjacent molars (26 and 27), and the forces were 150-200 g by elastic power chain. Kuroda et al. [14] performed group distalization of the maxillary dentition using multibrackets and TADs, and 9 teeth were moved distally through the MS bilaterally with a load of $200 \mathrm{~g}$ by coil spring. Oh et al. [16], Park et al. [15], Saglam et al. [21] and Carvalho et al. [20] used multibrackets to move maxillary teeth mesially or distally through the MS (TADs were utilized in Park et al.'s article). In these reports, "light forces" or "mild to moderate forces" were used. Generally, light to moderate forces $(50-200 \mathrm{~g})$ were applied to accomplish MTTMS.

\section{Tooth movement type}

In general, 7 articles reported MTTMS in the sagittal direction [14-17, 20-22], and 2 articles reported molar intrusion into the MS in the vertical direction $[18,19]$. 


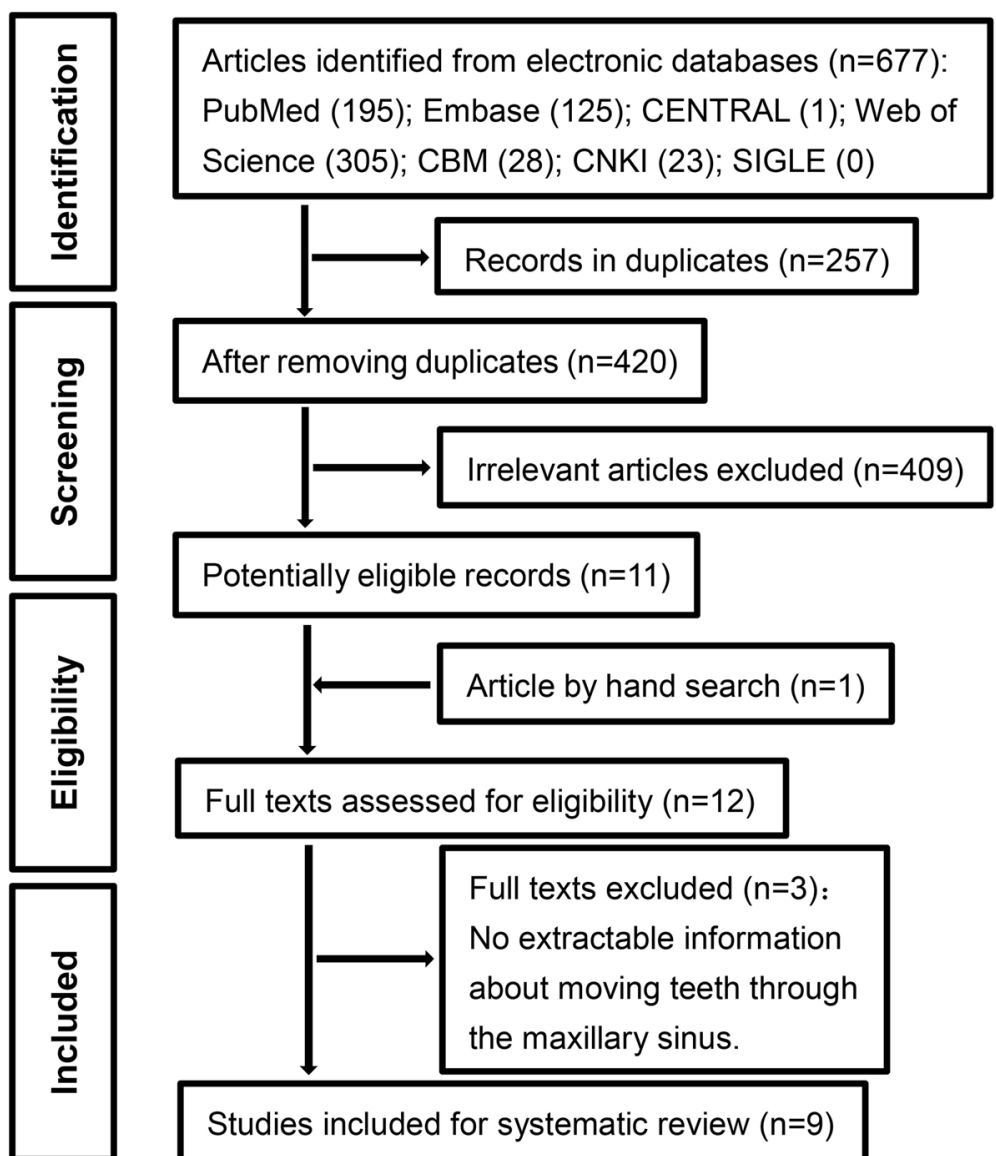

Fig. 1 PRISMA flow diagram showing the search and selection process

For tooth movement in the sagittal direction, all authors reported distal or mesial bodily movement of the target teeth [14-22]. However, Cacciafesta et al. [17], Re et al. [22], Oh et al. [16], Park et al. [15] and Kuroda et al. [14] revealed that the overall translation consisted of processes of initial tipping followed by up-righting. Saglam et al. [21] and Carvalho et al. [20] described distal bodily movement of the second premolars, but no details were provided in their reports. For molar intrusion into the MS, Yao et al. reported intrusion of tooth numbers 26 and 27 with slight distal tipping [19], while Kravitz et al. reported intrusion of tooth number 16 with palatal crown tipping [18].

\section{Duration and rate of tooth movement}

For tooth movement in the sagittal direction, Re et al. moved tooth number 25 by $6 \mathrm{~mm}$ distally in 6 months [22]. Oh et al. reported distal movement of $5 \mathrm{~mm}$ for tooth number 25 , mesial movement of $10 \mathrm{~mm}$ for tooth number 28 , and opposing movement of $10 \mathrm{~mm}$ between tooth numbers 15 and 17 in 70 months [16]. Opposing movements of $2-3 \mathrm{~mm}$ between tooth numbers 14 and 16 and 1-2 mm between tooth numbers 24 and 26 were achieved in 30 months in Park et al.'s article [15].
Carvalho et al. moved tooth number 15 by $7 \mathrm{~mm}$ distally in 6 months [20]. In addition, Kuroda et al. achieved group distalization of the maxillary dentition of 4-5 mm in 28 months [14]. For tooth movement in the vertical direction, 3-mm intrusion in 5 months and 4.4-mm intrusion in 6 months for molars were reported by Yao et al. and Kravitz et al., respectively [18, 19]. Overall, for molar intrusion into the MS, the individual cases showed a rate of $0.6-0.7 \mathrm{~mm} / \mathrm{month}$, and for distal-mesial movement, rates of $0.16-1.17$ and $0.05-0.16 \mathrm{~mm} /$ month were reported for premolars and molars, respectively.

\section{Alveolar bone formation and remolding of the sinus floor}

Re et al. [22], Saglam et al. [21], and Carvalho et al. [20] moved the second premolars distally through the MS with pneumatization into the alveolar bone. Alveolar bone formation occurred in the moving direction, along with direct remolding of the sinus lamina dura and sinus lift, and implants were subsequently inserted in the previous positions of the second premolars. Likewise, alveolar bone formation was observed in the studies of Cacciafesta et al. [17] and Oh et al. [16], and signs of sinus wall modeling were also observed in $\mathrm{Oh}$ et al.'s 


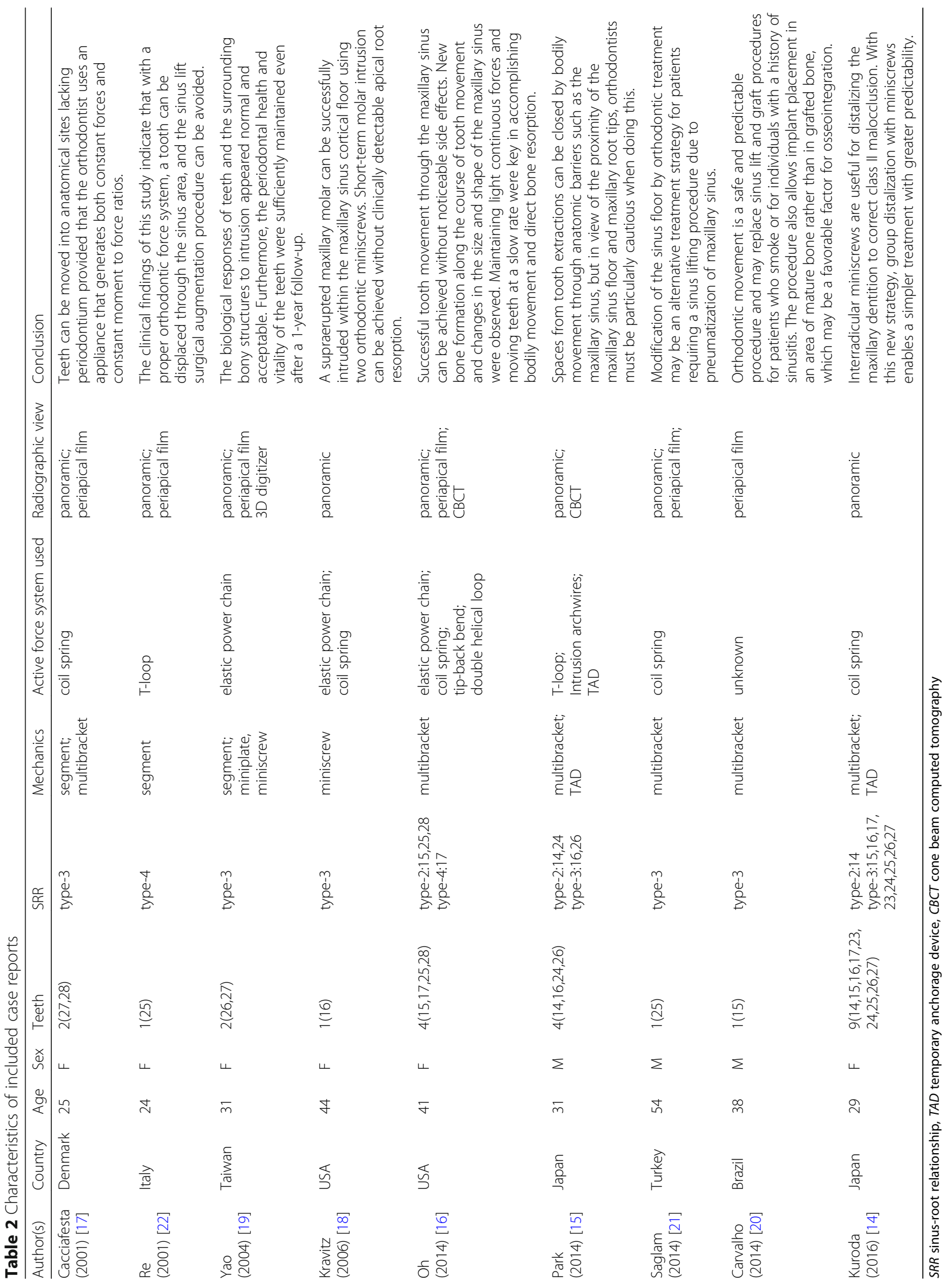


Table 3 Outcomes of the 9 included case reports

\begin{tabular}{|c|c|c|c|c|c|c|c|c|}
\hline Author(s) & SRR & $\begin{array}{l}\text { Force } \\
\text { magnitude }\end{array}$ & $\begin{array}{l}\text { Moving } \\
\text { distance } \\
\text { through sinus }\end{array}$ & Duration & $\begin{array}{l}\text { Tooth } \\
\text { movement type }\end{array}$ & $\begin{array}{l}\text { Bone forming } \\
\text { and remodeling } \\
\text { of the sinus floor }\end{array}$ & Side effects & $\begin{array}{l}\text { Follow-up } \\
\text { and relapse }\end{array}$ \\
\hline $\begin{array}{l}\text { Cacciafesta } \\
\text { (2001) [17] }\end{array}$ & type-3 & $50 \mathrm{~g}$ & $\begin{array}{l}\text { 4-5 mm } \\
\text { (half the width } \\
\text { of a molar) }\end{array}$ & unknown & $\begin{array}{l}\text { bodily mesially; } \\
\text { up-righting }\end{array}$ & $\begin{array}{l}\text { Bone formation } \\
\text { took place. }\end{array}$ & $\begin{array}{l}\text { minimal root } \\
\text { blunting; No } \\
\text { marginal bone } \\
\text { loss was visible. }\end{array}$ & unknown \\
\hline $\begin{array}{l}\operatorname{Re} \\
(2001)[22]\end{array}$ & type-4 & $50 \mathrm{~g} / \mathrm{mm}$ & $6 \mathrm{~mm}$ & 6 months & $\begin{array}{l}\text { bodily distally } \\
\text { (tipping, translation, } \\
\text { root movement) }\end{array}$ & $\begin{array}{l}\text { Alveolar bone } \\
\text { formation and } \\
\text { direct remodeling } \\
\text { of the sinus lamina } \\
\text { dura occurred. }\end{array}$ & $\begin{array}{l}\text { Pulp vitality, } \\
\text { bone support } \\
\text { and normal } \\
\text { width of the } \\
\text { periodontal } \\
\text { ligament were } \\
\text { maintained. }\end{array}$ & unknown \\
\hline $\begin{array}{l}\text { Yao } \\
\text { (2004) [19] }\end{array}$ & type-3 & $150-200 \mathrm{~g}$ & $3 \mathrm{~mm}$ & 5 months & $\begin{array}{l}\text { intrusion, slight } \\
\text { distal tipping }\end{array}$ & $\begin{array}{l}\text { The lamina dura } \\
\text { followed molar } \\
\text { intrusion and bone } \\
\text { remodeling was } \\
\text { achieved. }\end{array}$ & $\begin{array}{l}\text { Periodontal } \\
\text { health and } \\
\text { vitality of the } \\
\text { teeth were } \\
\text { maintained. }\end{array}$ & $\begin{array}{l}1 \text { year; } \\
\text { Periodontal } \\
\text { health and } \\
\text { vitality of } \\
\text { the teeth } \\
\text { were well } \\
\text { maintained. }\end{array}$ \\
\hline $\begin{array}{l}\text { Kravitz } \\
(2006)[18]\end{array}$ & type-3 & $100-150 \mathrm{~g}$ & $4.4 \mathrm{~mm}$ & 6 months & $\begin{array}{l}\text { intrusion, palatal } \\
\text { crown tipping }\end{array}$ & $\begin{array}{l}\text { Radiograph } \\
\text { showed intact } \\
\text { lamina dura around } \\
\text { the first molar } \\
\text { within the floor. }\end{array}$ & $\begin{array}{l}\text { no } \\
\text { radiographically } \\
\text { evident root } \\
\text { resorption. }\end{array}$ & unknown \\
\hline $\begin{array}{l}\text { Oh } \\
\text { (2014) [16] }\end{array}$ & $\begin{array}{l}\text { type-2:15,25,28 } \\
\text { type-4:17 }\end{array}$ & $\begin{array}{l}\text { light } \\
\text { forces }\end{array}$ & $\begin{array}{l}\text { 25: } 6 \mathrm{~mm} ; \\
\text { 28: } 10 \mathrm{~mm} ; \\
10 \mathrm{~mm}(15-17)\end{array}$ & 70 months & $\begin{array}{l}\text { 25: bodily distally } \\
\text { (tipping, up-righting); } \\
\text { 28: bodily mesially } \\
\text { (tipping, up-righting); } \\
\text { 15: bodily distally; } \\
\text { 17: bodily mesially }\end{array}$ & $\begin{array}{l}\text { Signs of sinus wall } \\
\text { modeling and new } \\
\text { alveolar bone } \\
\text { deposition were } \\
\text { observed in the } \\
\text { direction of tooth } \\
\text { movement. }\end{array}$ & $\begin{array}{l}\text { No apparent } \\
\text { root resorption } \\
\text { was observed, } \\
\text { and the alveolar } \\
\text { bone level was } \\
\text { maintained. }\end{array}$ & $\begin{array}{l}18 \text { months; } \\
\text { Occlusion } \\
\text { and normal } \\
\text { overjet and } \\
\text { overbite } \\
\text { were } \\
\text { maintained. }\end{array}$ \\
\hline $\begin{array}{l}\text { Park } \\
\text { (2014) [15] }\end{array}$ & $\begin{array}{l}\text { type-2:14,24 } \\
\text { type-3:16,26 }\end{array}$ & $\begin{array}{l}\text { light } \\
\text { forces }\end{array}$ & $\begin{array}{l}\text { 14-16: } \\
\text { (bodily 2-3 mm, } \\
\text { up-righting } \\
15-20^{\circ} \text { ) } \\
24-26: \\
\text { (bodily 1-2 mm, } \\
\text { up-righting } \\
20-25^{\circ} \text { ) }\end{array}$ & 30 months & $\begin{array}{l}\text { 14, 24: bodily distally, } \\
\text { up-righting; } \\
\text { 16, 26: bodily mesially, } \\
\text { rotated mesially, } \\
\text { up-righting }\end{array}$ & $\begin{array}{l}\text { The floor of the } \\
\text { sinus did not } \\
\text { displace coronally } \\
\text { during orthodontic } \\
\text { approximation of } \\
\text { these teeth. }\end{array}$ & $\begin{array}{l}\text { Some areas } \\
\text { showed signs } \\
\text { of apical root } \\
\text { resorption. }\end{array}$ & $\begin{array}{l}1 \text { year; } \\
\text { Stable } \\
\text { occlusion } \\
\text { and the } \\
\text { orthodontic } \\
\text { treatment } \\
\text { results were } \\
\text { maintained. }\end{array}$ \\
\hline $\begin{array}{l}\text { Saglam } \\
\text { (2014) [21] }\end{array}$ & type-3 & unknown & $7 \mathrm{~mm}$ & unknown & bodily distally & $\begin{array}{l}\text { Alveolar bone } \\
\text { formation and } \\
\text { remodeling of } \\
\text { the sinus floor } \\
\text { occurred. }\end{array}$ & $\begin{array}{l}\text { Maintained pulp } \\
\text { vitality and bone } \\
\text { support without } \\
\text { loss of the } \\
\text { connective } \\
\text { tissue } \\
\text { attachment. }\end{array}$ & $\begin{array}{l}2 \text { years; } \\
\text { Acceptable } \\
\text { intraoral } \\
\text { tissue } \\
\text { health was } \\
\text { observed } \\
\text { after } 2 \text { years. }\end{array}$ \\
\hline $\begin{array}{l}\text { Carvalho } \\
\text { (2014) [20] }\end{array}$ & type-3 & $\begin{array}{l}\text { mild and } \\
\text { moderate }\end{array}$ & $7 \mathrm{~mm}$ & 6 months & bodily distally & $\begin{array}{l}\text { The cortical bone } \\
\text { and sinus mucosa } \\
\text { displaced the } \\
\text { maxillary sinus floor } \\
\text { during bone and } \\
\text { periodontal } \\
\text { remodeling. }\end{array}$ & $\begin{array}{l}\text { Radiographically } \\
\text { evident root } \\
\text { resorption was } \\
\text { observed. }\end{array}$ & unknown \\
\hline $\begin{array}{l}\text { Kuroda } \\
\text { (2016) [14] }\end{array}$ & $\begin{array}{l}\text { type-2: } 14 \\
\text { type-3:15,16,17, } \\
23,24,25,26,27\end{array}$ & $200 \mathrm{~g}$ & $4-5 \mathrm{~mm}$ & 28 months & $\begin{array}{l}\text { bodily distally } \\
\text { (tipping, up-righting) }\end{array}$ & unknown & $\begin{array}{l}\text { No serious } \\
\text { root resorption. }\end{array}$ & $\begin{array}{l}5 \text { years; } \\
\text { Occlusion } \\
\text { and facial } \\
\text { profile were } \\
\text { stable. }\end{array}$ \\
\hline
\end{tabular}


study. In terms of molar intrusion, Yao et al. and Kravitz et al. found that the lamina dura followed the course of molar intrusion, and bone remolding during intrusion was achieved in Yao et al.'s case $[18,19]$.

\section{Safety and side effects}

First, radiographically evident OIRR was reported by Cacciafesta et al. [17], Park et al. [15] and Carvalho et al. [20], whereas no apparent OIRR was reported by Kravitz et al. [18], Oh et al. [16] and Kuroda et al. [14]. Second, no perforation of the sinus floor or loss of pulp vitality was reported in the 9 cases [14-22]. Third, standard periodontal control measures were adapted by Cacciafesta et al., Re et al., Oh et al., and Saglam et al. [16, 17, 21, 22], and they reported that bone support and periodontal health were maintained. Similar result was observed by Yao et al. [19].

\section{Stability and relapse}

Oh et al. [16], Park et al. [15] and Kuroda et al. [14] reported stable occlusion after follow-ups of 1.5, 1 and 5 years, respectively. The periodontal health and vitality of the teeth were maintained in Yao et al.'s case [19]. Saglam et al. reported acceptable intraoral tissue health after 2 years [21].

\section{Discussion}

This systematic review intended to determine the feasibility, safety and stability of current interventions for MTTMS. Nine case reports representing the available human clinical studies were included. In general, the present study indicated the feasibility of MTTMS. However, the difficulty of the moving process varied substantially, possibly indicating the heterogeneity among clinical measures and internal anatomic structures and the inherent bias of case reports.

In MTTMS, bodily movement is desired. The key biomechanical objective is uniform distribution of orthodontic forces along the PDL and the line of the active force passing through the center of resistance $[29,30]$. Carefully designed segments or TADs can produce approximate determinate force systems and may facilitate bodily movement $[9,17,31,32]$. Considering the anatomic variability of the MSF and the complexity of the SRR [8], techniques for better control in three dimensions should be developed, especially for patients with primarily regional complaints. To achieve tooth movement by frontal resorption, mild and constant forces (35-60 g, 70-120 g and 10-20 g for tipping, bodily and intrusion movement, respectively) are recommended. However, considering the amount of resistance in sliding mechanics $[9,30]$, the decay rate of forces and the root numbers of the posterior teeth, the magnitude of 50$200 \mathrm{~g}$ of force applied in the included cases seems safe.
In the present study, most cases showed initial stages of tipping through the MS, which is consistent with a previous study [33]. Deviation from ideal bodily movement may reflect expression of a well-designed pure Newtonian mathematical force system applied on the in vivo PDL. Orthodontic forces are derived from deformation of some parts of existing appliances; however, each appliance has a particular load deflection rate, and the decay rates of the counterparts (i.e., the moment of force and the moment of couple) in the equilibrium system are not equal, and consequently, the moment to force ratio constantly changes, resulting in constant changes in the center of rotation and difficulty in maintaining translation [34]. Moreover, in the MS, the distribution of bone density along the axis of a tooth must be considered. The coronal part of the root is more likely to move against cancellous bone while the apical part is more likely to move against cortical bone [9]. Therefore, the tooth is easily tipped toward the moving direction. Furthermore, for molar intrusion, the accompanying tipping may reflect different resistances among roots [19].

Moving at low speeds is a prerequisite for compensatory bone regeneration $[16,35]$. Therefore, applying light and continuous forces is the best strategy to achieve the ideal speed for moving teeth. Particularly, the cask effect regarding the moving rate in MTTMS is probably due to cortical anchorage [9]. In Oh et al.'s case, the location of the roots against the cortical bone of the sinus wall provided nearly absolute anchorage in the first 3.5 years [16]. In such cases, only light forces are appropriate as heavy forces against the cortical bone will reinforce the anchorage and cause additional OIRR. However, individual heterogeneity may exist in this regard because no other authors reported such an extreme situation, and a wide range of rate was reported across cases.

According to the theory of tooth movement, new physiological bone along the course of the moved tooth can be harvested $[9,36]$. In the past few decades, the development of implant sites with the help of orthodontic tooth movement has been shown to be practical [36], and in several cases, this technique was successfully applied in the MS area [20-22]. One major concern, however, is maintaining the intact membrane of the sinus floor. First, in surgical sinus augmentation procedures, the floor is mechanically and instantaneously lifted by applying graft materials or alveolar bone blocks [37, 38]. This shows the endurance and reparability of the sinus floor as it may adapt to slow and mild tooth movement. Second, recent studies have revealed that under stressful stimulation, bone deposition on the sinus side preceded resorption on the PDL side, and the amount of bone in the sinus wall was maintained or increased. This mechanism may partially account for bone remolding of the sinus floor $[11,12]$. 
Currently, the etiology of OIRR is unclear. However, comprehensive orthodontic treatment, particularly the application of heavy forces, undoubtedly cause increases in the incidence and severity of root resorption [39]. Moving a tooth against the cortical bone is more likely to cause heavy root resorption, but serious OIRR was not reported in any of the included cases, perhaps because of the light forces applied. However, lack of detection of serious OIRR in some cases may reflect a limitation of radiographic approaches [18, 19, 22]. On the one hand, there is hysteresis between histological and radiographical changes, and early root resorption could only be detected on radiographs after 6-12 months [39]. On the other hand, panoramics or periapical films were used in most cases [14, 17-22], but their diagnostic accuracy may be insufficient [39, 40]. For retention, wrap-around or bonded retainers were mainly used for the maxillary teeth, and implants and subsequent prosthetic crowns were installed adjacent to or opposing the moved teeth. All these factors contributed to good retention and stability after MTTMS.

\section{Limitations}

Currently, the comprehension of MTTMS is limited. First, prospective controlled clinical trials with large samples are not available, so an optimal orthodontic protocol has not been established. Second, the techniques used to evaluate the SRR, OIRR and perforation of the sinus floor have low accuracy [41] and applying panoramics and periapical films can introduce errors in patient selection or outcome measurements. To improve accuracy, CBCT is an alternative strategy $[8,24,25,40,42]$. Third, the results of basic research simulating MTTMS are not necessarily authentic. Although the discovery of recent research was novel and was partly consistent with some clinical observations [11-13], the studies involved only a 2-week observation period on mouse models. And the results were not entirely consistent with the long-term findings in a previous biopsy report in human in which osteoclasts and obvious lamina dura resorption were observed on the sinus side [41]. Therefore, more basic studies with consistent models should be conducted to confirm these results. Lastly, during orthodontic tooth movement, some side effects such as severe root resorption, osseous perforation, and sinus perforation may be beyond orthodontists' control. These cannot be macroscopically or radiologically detected but can be verified histologically. Clinicians should determine accurate diagnoses with consideration of anatomical structures before treatment, execute careful protocols, and conduct progress evaluations throughout treatment [39-41].

\section{Conclusion}

At the present stage, no evidence-based protocol could be recommended to guide MTTMS. The empirical application of constant and light to moderate forces (by TAD, segment and multibrackets) to slowly move teeth through or into the maxillary sinus in adults appears to be practical and secure. Bodily movement could be accomplished, but teeth seem to be easily tipped initially, potentially resulting in root resorption. However, this conclusion should be interpreted with caution as the currently available evidence is based on only a few case reports or case series, and longitudinal or controlled studies are lacking in this area.

\section{Abbreviations \\ CBCT: Cone-beam computed tomography; MS: Maxillary sinus; MSF: Maxillary sinus floor; MTTMS: Moving teeth through the maxillary sinus; \\ OIRR: Orthodontically induced root resorption; SRR: Sinus-root relationship \\ Funding \\ The National Natural Science Foundation of China (Nos. 81470722 and 81201379) supported the design of the study and collection, analysis, and interpretation of data and writing and publishing the manuscript.}

\section{Availability of data and materials}

The summary of data extraction in this study is available upon request to the corresponding author.

\section{Authors' contributions}

WS, KX, JL conducted the data search, extraction, assessment and the statistical analysis and draft the manuscript. XH made the figures and tables. XC, QL organized the structure of the manuscript and edited the language. WS and $J \mathrm{~L}$ designed the study and revised the manuscript. All authors read and approved the final version of submission.

Ethics approval and consent to participate

Not applicable.

\section{Competing interests}

The authors declare that they have no competing interests.

\section{Publisher's Note}

Springer Nature remains neutral with regard to jurisdictional claims in published maps and institutional affiliations.

\section{Author details \\ ${ }^{1}$ State Key Laboratory of Oral Diseases, National Clinical Research Center for Oral Diseases, Department of Orthodontics, West China Hospital of Stomatology, Sichuan University, Chengdu 610041, China. ${ }^{2}$ State Key Laboratory of Oral Diseases, National Clinical Research Center for Oral Diseases, Department of Oral and Maxillofacial Surgery, West China Hospital of Stomatology, Sichuan University, Chengdu 610041, China.}

Received: 30 January 2018 Accepted: 17 May 2018

Published online: 23 May 2018

\section{References}

1. Rossini G, Parrini S, Castroflorio T, Deregibus A, Debernardi CL. Efficacy of clear aligners in controlling orthodontic tooth movement: a systematic review. Angle Orthod. 2015;85:881-9.

2. Rossini G, Parrini S, Castroflorio T, Deregibus A, Debernardi CL. Diagnostic accuracy and measurement sensitivity of digital models for orthodontic purposes: a systematic review. Am J Orthod Dentofac Orthop. 2016;149:161-70. 
3. Cassetta M, Giansanti M, Di Mambro A, Calasso S, Barbato E. Minimally invasive corticotomy in orthodontics using a three-dimensional printed CAD/CAM surgical guide. Int J Oral Maxillofac Surg. 2016;45:1059-64.

4. Melsen B. Adult orthodontics. 1st ed. UK: Wiley-Blackwell; 2012. p. 382-3.

5. von Arx T, Lozanoff S. Maxillary sinus clinical oral anatomy: a comprehensive review for dental practitioners and researchers. Cham: Springer International Publishing; 2017. p. 163-97.

6. Matsuda H, Borzabadi-Farahani A, Le BT. Three-dimensional alveolar bone anatomy of the maxillary first molars: a cone-beam computed tomography study with implications for immediate implant placement. Implant Dent. 2016;25:367-72

7. Ahn NL, Park HS. Differences in distances between maxillary posterior root apices and the sinus floor according to skeletal pattern. Am J Orthod Dentofac Orthop. 2017;152:811-9.

8. Sharan A, Madjar D. Correlation between maxillary sinus floor topography and related root position of posterior teeth using panoramic and crosssectional computed tomography imaging. Oral Surg Oral Med Oral Pathol Oral Radiol Endod. 2006;102:375-81.

9. Proffit WR, Fields HW Jr, Sarver DM. Contemporary orthodontics. 4th ed. St Louis: C.V. Mosby; 2007. p. 287-300-331-430.

10. Wehrbein $\mathrm{H}$, Diedrich $\mathrm{P}$. The initial morphological state in the basally pneumatized maxillary sinus-a radiological-histological study in man. Fortschr Kieferorthop. 1992;53:254-62.

11. Maeda Y, Kuroda S, Ganzorig K, Wazen R, Nanci A, Tanaka E. Histomorphometric analysis of overloading on palatal tooth movement into the maxillary sinus. Am J Orthod Dentofac Orthop. 2015;148:423-30.

12. Kuroda S, Wazen R, Moffatt $P$, Tanaka E, Nanci A. Mechanical stress induces bone formation in the maxillary sinus in a short-term mouse model. Clin Oral Investig. 2013;17:131-7.

13. Daimaruya T, Takahashi I, Nagasaka H, Umemori M, Sugawara J, Mitani H. Effects of maxillary molar intrusion on the nasal floor and tooth root using the skeletal anchorage system in dogs. Angle Orthod. 2003;73:158-66.

14. Kuroda S, Hichijo N, Sato M, Mino A, Tamamura N, Iwata M, et al. Long-term stability of maxillary group distalization with interradicular miniscrews in a patient with a class II division 2 malocclusion. Am J Orthod Dentofac Orthop. 2016;149:912-22

15. Park JH, Tai K, Kanao A, Takagi M. Space closure in the maxillary posterior area through the maxillary sinus. Am J Orthod Dentofac Orthop. 2014;145: 95-102.

16. Oh H, Herchold K, Hannon S, Heetland K, Ashraf G, Nguyen V, et al. Orthodontic tooth movement through the maxillary sinus in an adult with multiple missing teeth. Am J Orthod Dentofac Orthop. 2014;146:493-505.

17. Cacciafesta $V$, Melsen B. Mesial bodily movement of maxillary and mandibular molars with segmented mechanics. Clin Orthod Res. 2001;4:182-8.

18. Kravitz ND, Kusnoto B, Tsay PT, Hohlt WF. Intrusion of overerupted upper first molar using two orthodontic miniscrews. A case report. Angle Orthod. 2007:77:915-22.

19. Yao CC, Wu CB, Wu HY, Kok SH, Chang HF, Chen YJ. Intrusion of the overerupted upper left first and second molars by mini-implants with partialfixed orthodontic appliances: a case report. Angle Orthod. 2004;74:550-7.

20. Savi de Carvalho R, Consolaro A, Francischone CE Jr, de Macedo Carvalho AP. Sinus augmentation by orthodontic movement as an alternative to a surgical sinus lift: a clinical report. J Prosthet Dent. 2014;112:723-6.

21. Saglam M, Akman S, Malkoc S, Hakki SS. Modification of maxillary sinus floor with orthodontic treatment and implant therapy: a case letter. J Oral Implantol. 2014;40:619-22.

22. Re S, Cardaropoli D, Corrente G, Abundo R. Bodily tooth movement through the maxillary sinus with implant anchorage for single tooth replacement. Clin Orthod Res. 2001;4:177-81

23. Moher D, Liberati A, Tetzlaff J, Altman DG. Preferred reporting items for systematic reviews and meta-analyses: the PRISMA statement. Bmj. 2009. 339:b2535.

24. Shanbhag S, Karnik P, Shirke P, Shanbhag V. Cone-beam computed tomographic analysis of sinus membrane thickness, ostium patency, and residual ridge heights in the posterior maxilla: implications for sinus floor elevation. Clin Oral Implants Res. 2014:25:755-60.

25. Janner SF, Caversaccio MD, Dubach P, Sendi P, Buser D, Bornstein MM Characteristics and dimensions of the Schneiderian membrane: a radiographic analysis using cone beam computed tomography in patients referred for dental implant surgery in the posterior maxilla. Clin Oral Implants Res. 2011;22:1446-53.
26. Hofmann E. Radiology of the nose and paranasal sinuses for the endoscopic sinus surgeon. In: Stucker FJ, de Souza C, Kenyon GS, Lian TS, Draf W, Schick B, editors. Rhinology and facial plastic surgery. Berlin, Heidelberg: Springer Berlin Heidelberg; 2009. p. 507-12.

27. Fatterpekar GM, Delman BN, Som PM. Imaging the paranasal sinuses: where we are and where we are going. Anat Rec (Hoboken). 2008;291:1564-72.

28. Aimetti M, Massei G, Morra M, Cardesi E, Romano F. Correlation between gingival phenotype and Schneiderian membrane thickness. Int J Oral Maxillofac Implants. 2008:23:1128-32.

29. Cattaneo PM, Dalstra M, Melsen B. Moment-to-force ratio, center of rotation, and force level: a finite element study predicting their interdependency for simulated orthodontic loading regimens. Am J Orthod Dentofac Orthop. 2008;133:681-9.

30. Graber LW, Vanarsdall RL Jr, Vig KWL. Orthodontics: current principles and techniques. 5th ed. Philadelphia: Mosby; 2012. p. 345-80.

31. Kravitz ND, Kusnoto B, Tsay TP, Hohlt WF. The use of temporary anchorage devices for molar intrusion. J Am Dent Assoc. 2007:138:56-64.

32. Manhartsberger C, Morton JY, Burstone CJ. Space closure in adult patients using the segmented arch technique. Angle Orthod. 1989;59:205-10.

33. Wehrbein $H$, Bauer W, Wessing $G$, Diedrich $P$. The effect of the maxillary sinus floor on orthodontic tooth movement. Fortschr Kieferorthop. 1990;51: 345-51.

34. Isaacson RJ, Lindauer SJ, Davidovitch M. On tooth movement. Angle Orthod. 1993:63:305-9.

35. Wingard CE, Bowers GM. The effects of facial bone from facial tipping of incisors in monkeys. J Periodontol. 1976:47:450-4.

36. Somar M, Mohadeb JV, Huang C. Predictability of orthodontic forced eruption in developing an implant site: a systematic review. J Clin Orthod. 2016;50:485-92.

37. Mohan N, Wolf J, Dym H. Maxillary sinus augmentation. Dent Clin N Am. 2015:59:375-88

38. Jensen OT, Brownd C, Baer D. Maxillary molar sinus floor intrusion at the time of dental extraction. J Oral Maxillofac Surg. 2006:64:1415-9.

39. Huang GJ, Richmond S, Vig KWL. Evidence-based orthodontics. 1st ed. UK: Wiley-Blackwell; 2011. p. 63-87.

40. Yi J, Sun Y, Li Y, Li C, Li X, Zhao Z. Cone-beam computed tomography versus periapical radiograph for diagnosing external root resorption: a systematic review and meta-analysis. Angle Orthod. 2017;87:328-37.

41. Wehrbein $H$, Fuhrmann RA, Diedrich PR. Human histologic tissue response after long-term orthodontic tooth movement. Am J Orthod Dentofac Orthop. 1995;107:360-71.

42. Lopes $\amalg$, Gamba TO, Bertinato JV, Freitas DQ. Comparison of panoramic radiography and $C B C T$ to identify maxillary posterior roots invading the maxillary sinus. Dentomaxillofac Radiol. 2016:45:20160043.

\section{Ready to submit your research? Choose BMC and benefit from:}

- fast, convenient online submission

- thorough peer review by experienced researchers in your field

- rapid publication on acceptance

- support for research data, including large and complex data types

- gold Open Access which fosters wider collaboration and increased citations

- maximum visibility for your research: over $100 \mathrm{M}$ website views per year

At BMC, research is always in progress.

Learn more biomedcentral.com/submissions 